LUBLIN STUDIES IN MODERN LANGUAGES AND

LITERATURE 41(1), 2017, HTTP://WWW.LSMLL.UMCS.LUBLIN.PL, HTTP://LSMLL.JOURNALS.UMCS.PL

\author{
Mustafa Şevik \\ Mehmet Akif Ersoy University \\ Antalya Burdur Yolu \\ 15030 Burdur, Turkey
}

\title{
An Investigation of ELT Student Teachers' Dictionary Ownership and Preferences
}

\begin{abstract}
Alongside with many societal changes, technology has also started to change the teaching and learning of EFL especially since the turn of the millennium. Multimedia-based and audiovisual materials are now easily accessible and available for both teachers and learners of EFL. Recent research demonstrates that EFL learner ownership and preferences about dictionaries seem to have taken its share from these technological innovations and influences. The increasing number of research on learners' dictionary ownership and preferences has tried to explore this rather recent situation and has mainly resulted in the main finding that paper dictionaries are losing their long-lasting popularity and that multimedia-based dictionaries are becoming popular among EFL learners.

This new situation that has pedagogical and curricular applications necessitates research on ELT student teachers' dictionary ownership and preferences in Turkey, especially considering that studies into this area are almost non-existent in Turkish ELT departments. Therefore, the primary aim of this study is to explore ELT student teachers' dictionary ownership and preferences. With this aim this paper reports on a descriptive study about dictionary ownership and preferences of 186 ELT student teachers at Mehmet Akif Ersoy University.
\end{abstract}


The results demonstrate that student teachers strongly believe that a language learner needs a dictionary; that paper dictionaries are mostly owned but multimedia based dictionaries are mostly preferred; that paper dictionaries are difficult to carry, expensive and time consuming; that they use their dictionaries mostly at home and secondly in class; and that their main reason for using the dictionary is to learn the meaning of vocabulary but not spelling or pronunciation. Keywords: English as a foreign language; university ELT department; dictionary ownership; dictionary preferences

1. Introduction

It would not be wrong to argue that anyone learning a foreign language should have and use a dictionary on a regular basis. Brumfit (1985), for example, describes dictionaries as the most widespread single language improvement device ever invented, but yet we need greater understanding of the dictionary since it is probably taken for granted most of the time. In fact, as argued by Stein (1989), dictionaries, regarded as lexicographical reference books, are considered as indispensable learning tools in foreign language acquisition.

Moreover, the dictionary is regarded as a tool that everyone uses since childhood. Its use is supposed to be familiar to all, the process of its use commonly understood. Its skills are so elementary that, in many people's mind, the training of them only belongs in the primary education curriculum. According to Tseng (2009), dictionaries are considered faithful companions to language learners, especially to second and foreign language learners because they provide a quick and direct access to the meaning of an unknown word. In fact, the supporting role of dictionaries has been emphasized by both teachers and researchers. Nowadays with the easy and widespread access to the Internet, more and more EFL students use online dictionaries when they encounter unknown words in their learning tasks. It is mainly because both online and electronic dictionaries can provide students with the information about the looked-up words easily and quickly. 
Dictionaries are often seen as a basic tool in the process of foreign language learning.

However, as argued by Şevik (2014), research on dictionary ownership, preference, attitudes and effects is not equally prominent in EFL contexts. In other words, there is generally a lack of research about dictionaries. Despite the importance of dictionaries for EFL learners, research into dictionary use has started to capture the deserved attention of language educators only in the last decade. Unfortunately, studies into dictionaries in Turkish EFL contexts are almost non-existent and we know very little or almost nothing about the behavior and preferences of EFL learners toward the dictionary. This situation may have many drawbacks for students, teachers, researchers and educators in that appropriate and significant pedagogical applications may be out of place since dictionary use has not been researched in Turkish EFL contexts.

Therefore, the purpose of the present study is to explore ELT student teachers' dictionary ownership and preferences in a Turkish university ELT department context. More specifically, the present study addresses the question of dictionary ownership and preferences of university ELT student teachers as regards to:

1. Background in dictionary usage

2. Kind of dictionary owned

3. Kind of dictionary used and usage frequency

4. Thoughts about kinds of dictionaries

5. Reasons for using dictionaries

The current study will shed light on an area of research in foreign language learning addressed by linguists worldwide, but neglected in Turkish university ELT department settings. The study findings will help to accomplish the following objectives:

- to explore ELT student teachers' background about dictionaries enrolled in a Turkish university,

- to determine kinds of dictionaries owned, used and usage frequency, 
- to explore ELT student teachers' thoughts about kinds of dictionaries,

- to explore the reasons as to why ELT student teachers use dictionaries.

\section{Literature review}

Hamouda (2013), who provides a useful comprehensive summary about research on dictionaries, claims that most L2 learners, including advanced learners, depend on dictionaries; that L2 learners most frequently use dictionaries for lexical meaning; that L2 learners primarily use dictionaries for written tasks; that L2 learners use bilingual dictionaries more widely than monolingual dictionaries; that high proficiency learners use monolingual dictionaries more extensively than lower proficiency learners although all learners continue to use bilingual dictionaries. L2 learners prefer to use edictionaries (electronic pocket dictionaries/PC based dictionaries/online dictionaries) more frequently than printed dictionaries, especially over the last decade. Finally, most L2 learners are not skilled enough in using dictionaries to make the maximum use of dictionaries and that they need explicit instruction about using dictionaries.

I believe that looking more in depth towards some of the research carried out about dictionaries will help us to understand the above summary more clearly. It will be a good starting point to start with Tomaszczyk (1979), who was one of the first researchers to investigate the dictionary requirements of non-native speakers of English. His results demonstrated that participants feel greater satisfaction with monolingual dictionaries but the majority prefers to use bilingual dictionaries and most learners $(85 \%)$ use the dictionary to find lexical meaning. A more frequently cited study of non-native speakers dictionary needs was conducted by Bejoint (1981) with 122 French students of English at the University of Lyon. Findings from this study revealed that $96 \%$ of the students possessed a monolingual dictionary. $85 \%$ of the respondents chose their dictionary because 
their tutor had recommended it. The majority of respondents $(87 \%)$ placed meaning among the three most sought-after pieces of information, but only 25\% mentioned spelling and pronunciation. Etymology was the least frequently mentioned information category. A similar survey carried out by Battenburg (1991) revealed that bilingual dictionaries were owned by the largest number of subjects, and native-speaker dictionaries by the smallest number. In general, there was a correlation between dictionary use and ownership. At more advanced levels, bilingual and monolingual learners' dictionaries decreased, and native speaker dictionary use increased. All subjects expressed a strong preference for looking up definitions, and a notable lack of interest in etymological information and little dictionary consultation was recorded for speaking and listening activities.

Hamouda's (2013) research on dictionary use by Saudi EFL students also revealed that the most frequently looked-up information is meaning (87\%), followed by spelling ( $72 \%)$, and pronunciation (52.4\%). The English-Arabic bilingual dictionary was seen as the most useful and most frequently used type of dictionary. A high percentage (91.9\%) preferred bilingual dictionaries to other types. Ryu's (2006) study also revealed that students favored bilingual dictionaries over monolingual dictionaries to find out the meaning of words. Likewise, Ali's (2012) study about monolingual dictionary use in an EFL context also revealed that a considerable number of the students do not like to use monolingual dictionaries. In fact Nation (2003) explains why L2 learners prefer bilingual dictionaries. This study has shown that for students to use a monolingual dictionary easily they need to know at least 2000 words in English. Students do not achieve this until after 5-6 years of language study. Therefore, research into dictionaries mostly shows that learners prefer bilingual dictionaries.

Recent research also shows that the majority of L2 learners prefer to use electronic dictionaries (pocket electronic dictionaries/online or Internet-based dictionaries/dictionaries on CD-ROMs) rather than paper dictionaries. Bower and McMillan's (2006) study, for example, 
revealed that $96 \%$ of the students owned electronic dictionaries and $90 \%$ of them were very active electronic dictionary users on reading and writing tasks (writing 53\% and reading 37\%). There has been a growing interest in the use of electronic dictionaries for learning foreign languages. Several studies have been conducted to evaluate students' perceptions of and attitudes toward the use of electronic dictionaries in educational contexts. In general, the findings of the majority of studies showed that students adopt positive attitudes toward the use of electronic dictionaries and find them beneficial and facilitative for their learning (Dashtestani, 2013). One of the reasons for preferring electronic dictionaries may be the average look-up time. In his experimental study, Weschler (2000) concluded that the average look-up time for ten words using a paper dictionary was 168 seconds (about 17 seconds per word), whereas using an electronic dictionary it was 130 seconds (about 13 seconds per word). In short, the students could look up words about $23 \%$ faster with an electronic dictionary.

Another common finding of research into dictionaries indicates that L2 learners do not know how to use dictionaries effectively and that most learners have not received any training about dictionary skills. Ali (2002), for example, indicates that recent studies focus on dictionary use training and argues that in all of these studies the majority of the students indicate that they never received dictionary use training. In his study, for example, nearly $70 \%$ of the students stated that they cannot use dictionaries effectively and another $54 \%$ stated that they needed training in using dictionaries. Chan (2005), who investigated the general use of dictionaries in English majors of universities in Hong Kong, also argues that students' dictionary skills were often not adequate for them to cope with their learning demand.

Commenting on research into dictionaries which examined students' use of paper dictionaries by analyzing their look-up errors, Tseng (2009) clearly states that learners do not know how to use dictionaries effectively. For example, the students had difficulty in selecting an appropriate meaning in a polysemous entry or they might select meanings from a wrong word entry due to their misidentification of the grammatical class of the looked-up word. 
These look-up error analysis studies may reveal students' lack of training in using dictionaries or be suggestive of their insufficient knowledge of the English language. Based on the errors students make and the difficulties they encounter in consulting dictionaries, teachers can provide proper instruction to students in the use of dictionaries. Therefore, the training of dictionary skills is considered important and necessary because EFL learners may not be able to make good use of dictionaries without explicit instruction.

A more recent study based in the Turkish EFL context carried out by Şevik (2014) with 157 university prep-school EFL learners revealed that $94 \%$ of the participants agreed that dictionaries are inevitable devices for EFL learners, but $48 \%$ cannot use dictionaries effectively and only $10 \%$ received training on dictionary use. This study also revealed that paper dictionaries were the mostly owned (97\%) and that cell phone dictionaries were the second mostly owned dictionary kind $(92 \%)$. Regardless of the kind of dictionary owned, bilingual dictionaries were the most popular and using electronic dictionaries online was the most favored method. As for the dictionary usage and the frequency of usage, cell phone dictionaries were the most favored (92\%) and paper dictionaries the second (87\%). This study concludes with the main finding that bilingual cell phone dictionaries were the mostly preferred and used.

\section{Methodology}

\subsection{Participants}

186 student teachers, all enrolled in Faculty of Education at Mehmet Akif Ersoy University, voluntarily participated in this study in the academic year 2015/2016. Out of the 186 participants 59 were first year student teachers, 39 second year, 45 third year and 43 fourth (final) year student teachers. The main reasons as to why the participant numbers are not equal on a year basis are that there were dropouts in the department and that the study was carried out on a voluntary basis. 129 participants $(69.35 \%)$ were female and the rest were male. The participants ranged in age from 18 to 26 , with a 
An Investigation of ELT Student Teachers' Dictionary Ownership ... 221

median age of 20.81. Since they are ELT department students, they can be termed as advanced learners.

\subsection{Instrument}

The questionnaire used in this study was adopted from Dashtestani (2013), Hasan (2013), and Şevik (2014). The questionnaire contained 5 sections composed of 50 prescriptive set of statements to which respondents marked their degree of agreement, and 3 open-ended questions to which respondents described the brand of their pocket electronic dictionaries, together with the name of the search engines, programs, CD's used as dictionaries.

The first section (6 items) asked respondents about their background in dictionary usage; the second section (10 prescriptive and 3 open-ended items) asked about kind of dictionary owned. On the other hand, the third section (10 items) elicited the kind of dictionary used and the usage frequency while the fourth section (18 items) concerned respondents' thoughts about kinds of dictionaries. Finally, the fifth section (6 items) inquired about the respondents' reasons for using dictionaries.

\subsection{Data collection and analysis}

Data were obtained by distributing the questionnaire to 194 students, all enrolled in Mehmet Akif Ersoy University in the academic year 2015/2016. However, only 186 questionnaires were eligible to be used in the study. The questionnaires were distributed and collected during class times. After summarizing and tabulating the information obtained from the questionnaire, descriptive statistics (percentages, means, and standard deviations) were computed for the questionnaire items.

\section{Results}

The results will be presented in five tables (as percentages and significance values) based on the research questions. 
4.1. Background in dictionary usage

As illustrated in Table 1, only 36 of the respondents (19\%) stated that they received training about how to use dictionaries; 139 (75\%) stated that they did not receive any training about how to use dictionaries; and another $11(6 \%)$ were undecided.

Table 1. Background in dictionary usage

\begin{tabular}{lcccccc}
\hline \multirow{2}{*}{ Statements } & \multicolumn{2}{c}{ Agree } & \multicolumn{2}{c}{ Disagree } & \multicolumn{2}{c}{ Undecided } \\
\cline { 2 - 7 } & $\mathbf{N}$ & $\mathbf{\%}$ & $\mathbf{N}$ & $\mathbf{\%}$ & $\mathbf{N}$ & $\mathbf{\%}$ \\
\hline $\begin{array}{l}\text { 1.I have received training about how } \\
\text { to use dictionaries }\end{array}$ & 36 & 19.35 & $\begin{array}{c}13 \\
9\end{array}$ & 74.73 & 11 & 5.91 \\
\hline $\begin{array}{l}\text { 2.I can use dictionaries effectively } \\
\text { 3. Someone learning English }\end{array}$ & 98 & 52.69 & 10 & 5.38 & 78 & 41.94 \\
\hline definitely needs a dictionary & 172 & 92.47 & 2 & 1,08 & 12 & 6.45 \\
\hline
\end{tabular}

It is, therefore, possible to argue that that the great majority of the respondents (81\%, including the undecided) did not receive any training in how to use dictionaries. 98 of the respondents (53\%) stated that they can use dictionaries effectively; 10 (5\%) disagreed; and 78 (42\%) were undecided. It can be argued that almost half of the respondents $(47 \%)$ somehow feel that they cannot use dictionaries effectively. This finding also strengttens previous arguments that EFL learners should explicitly be instructed about using dictionaries. 172 of the respondents (93\%) agreed that English language learners definitely need dictionaries; $2(1 \%)$ disagreed; and $12(6 \%)$ were undecided. The belief that English language learners need dictionaries has the strongest agreement level with 93\% among the three items and in contrast, training in how to use dictionaries has the strongest disagreement level with $75 \%$, finally, the strongest level of indeciciveness was on effective use of dictionaries with $42 \%$. 
An Investigation of ELT Student Teachers' Dictionary Ownership ... 223

4.2. Kind of dictionary owned

Table 2 reveals that PDs are the mostly owned (96.77\%) dictionary kind. 20\% of the respondents own monolingual (English-English) PDs, $10 \%$ own bilingual (English-Turkish/Turkish-English) PDs, and the greatest majority (67\%) own both monolingual and bilingual PDs.

Table 2. Kind of dictionary owned ${ }^{1}$

\begin{tabular}{lcccccc}
\hline \multicolumn{1}{c}{ Statements } & \multicolumn{2}{c}{$\begin{array}{c}\text { Yes/E- } \\
\text { E/Online }\end{array}$} & $\begin{array}{c}\text { No/E-T-T- } \\
\text { E/Downloa } \\
\text { dedProgra } \\
\text { m/CD- } \\
\text { ROM }\end{array}$ & $\begin{array}{l}\text { Both/Down } \\
\text { loaded } \\
\text { Program }\end{array}$ \\
\cline { 2 - 7 } & N & \% & N & \% & N & \% \\
\hline 1.I have a paper dictionary (PD). & 180 & 96.77 & 6 & 3.23 & $\begin{array}{c}\text { N } \\
\text { A }\end{array}$ & NA \\
\hline 2.My PD is & 37 & 19.89 & 18 & 9.68 & $\begin{array}{c}12 \\
5\end{array}$ & 67.20 \\
\hline $\begin{array}{l}\text { 3.I have a pocket electronic dictionary } \\
\text { (PED) }\end{array}$ & 41 & 22.04 & 14 & 77.96 & $\begin{array}{c}\text { N } \\
\text { A }\end{array}$ & NA \\
\hline 4.My PED is & 5 & 2.69 & 10 & 5.38 & 26 & 13.98 \\
\hline $\begin{array}{l}\text { 5.I use my cell phone (CP) as } \\
\text { dictionary }\end{array}$ & 159 & 85.48 & 27 & 14.52 & $\begin{array}{c}\text { N } \\
\text { A }\end{array}$ & NA \\
\hline 6.The dictionary in my CP is & 18 & 9.68 & 46 & 24.73 & 95 & 51.08 \\
\hline 7. The dictionary in my CP & 54 & 29.03 & 69 & 37.10 & 33 & 17.74 \\
\hline 8.I use my PC/laptop as dictionary & 148 & 79.57 & 38 & 20.43 & $\begin{array}{c}\text { N } \\
\text { A }\end{array}$ & NA \\
\hline 9. The dictionary in my PC/laptop is & 22 & 11.83 & 17 & 9.14 & $\begin{array}{c}11 \\
0\end{array}$ & 59.14 \\
\hline 10. The dictionary in my PC/laptop & 86 & 46.24 & 14 & 7.53 & 49 & 26.34 \\
\hline
\end{tabular}

Cell Phone Dictionary (CPD) ownership is the respondents' second highest preference with $85.48 \%$, and that $10 \%$ of the respondents own monolingual CPDs, $25 \%$ own bilingual CPDs, and that the majority

\footnotetext{
${ }^{1}$ For questions 1,3,5,8: Yes/No

For questions 2,4,6,9: E-E (English-English)/English-Turkish-Turkish-English (E-T-

T-E)/both, For question 7: online/downloaded program/both

For question 10: online/CD-ROM/downloaded program
} 
$51 \%$ own both monolingual and bilingual CPDs. 29\% stated that they own online CPDs, $37 \%$ have downloaded a dictionary program, and $18 \%$ own CPDs both online and with various programs. In addition, $62 \%(\mathrm{~N}=116)$ of the respondents replied the question about their most preferred online web sites and programs as their CPDs. Out of the 116 who replied, 37\% (N=43) preferred "tureng.com", 15\% preferred "zargan.com", 14\% preferred "translate.google.com", and the remaining named various other web sites and programs.

PC Dictionary (PCD) ownership is the respondents' third highest preference with $79.57 \%$, and that $12 \%$ of the respondents own monolingual PCDs, 9\% own bilingual PCDs, and that the majority $59 \%$ own both monolingual and bilingual PCDs. The majority $46 \%$ stated that they own online PCDs, $8 \%$ own CD-ROMs and $26 \%$ have downloaded various dictionary programs. In addition, 67\% ( $\mathrm{N}=125)$ of the respondents replied the question about their most preferred online web sites, CD-ROMs and programs as their PCDs. Out of the 125 who replied, 22\% ( $\mathrm{N}=28)$ preferred "translate.google.com", $21 \%$ $(\mathrm{N}=26)$ preferred "tureng.com", 20\% ( $\mathrm{N}=25)$ owned the "Oxford $\mathrm{CD}-$ ROM", $12 \%(\mathrm{~N}=15)$ owned the "Cambridge CD-ROM", 10\% $(\mathrm{N}=13)$ owned the "Longman CD-ROM, and the remaining 14\% ( $\mathrm{N}=18)$ named other web sites, programs and CD-ROMs.

Finally, PED ownership is the least preferred with only $22 \%$ of the respondents. Out of those who own PEDs, 3\% own monolingual PEDs, 5\% own bilingual PEDs, and the majority 26\% own both monolingual and bilingual PEDs. In addition, $12 \%(\mathrm{~N}=23)$ of the respondents replied the question about their most preferred brand as their PEDs. Out of the 23 who replied, 7 respondents stated that they own a "Redhouse-PED", and another 7 respondents stated that they own a "Poly Lingua-PED", and the remaining 9 respondents stated that they owned various other brands.

\subsection{Kind of dictionary used and frequency}

Table 3 reveals that using the Internet as dictionary is the learners' first choice $(92.47 \%$ ), and $38.17 \%$ use the Internet as dictionaries more than once a day and another $11.83 \%$ once a day. Using CPs as 
An Investigation of ELT Student Teachers' Dictionary Ownership ... 225

dictionaries is the learners' second choice (84.95\%), 55.38\% use their CPs as dictionies more than once a day and another $10.22 \%$ once a day. Using PDs is the learners' third choice (83.33\%), and $23.66 \%$ use their PDs more than once a day and another $10.22 \%$ once a day. However, overall using CPs as dictionaries seems to be the most frequent of the three with a total of $65.60 \%$ of average usage on a daily basis. PEDs are the least used kind of dictionaries with only $19.35 \%$, and even less frequent usage with $7.53 \%$ using PEDs more than once a day and only another $2.69 \%$ once a day.

Table 3. Kind of dictionary used and frequency ${ }^{2}$

\begin{tabular}{lcccccccc}
\hline \multicolumn{1}{c}{ Statements } & $\begin{array}{c}\text { Yes/More } \\
\text { than once } \\
\text { day }\end{array}$ & $\begin{array}{c}\text { No/Once a } \\
\text { day }\end{array}$ & $\begin{array}{c}\text { 4-6 times a } \\
\text { week }\end{array}$ & $\begin{array}{c}\text { 1-3 times a } \\
\text { week }\end{array}$ \\
\cline { 2 - 9 } & $\mathbf{N}$ & $\mathbf{\%}$ & $\mathbf{N}$ & $\mathbf{\%}$ & $\mathbf{N}$ & $\mathbf{\%}$ & $\mathbf{N}$ & \% \\
\hline $\begin{array}{l}\text { 1.I use my paper } \\
\text { dictionary (PD) }\end{array}$ & 155 & 83.33 & 31 & 16.67 & NA & & NA & \\
\hline 2. I use my PD & 44 & 23.66 & 19 & 10.22 & 36 & 19.35 & 56 & 30.11 \\
\hline 3. I use my PED & 36 & 19.35 & 150 & 80.65 & NA & & NA & \\
\hline 4. I use my PED & 14 & 7.53 & 5 & 2.69 & 7 & 3.76 & 10 & 5.38 \\
\hline $\begin{array}{l}\text { 5. I use my CP as } \\
\text { dictionary }\end{array}$ & 158 & 84.95 & 28 & 15.05 & NA & & NA & \\
\hline $\begin{array}{l}\text { 6. I use my CP as } \\
\text { dictionary }\end{array}$ & 103 & 55.38 & 19 & 10.22 & 20 & 10.75 & 16 & 8.60 \\
\hline 7. I use my PC/laptop as & 145 & 77.96 & 41 & 22.04 & NA & & NA & \\
\hline
\end{tabular}

${ }^{2}$ For questions 1/3/5/7/9: Yes/No

For questions 2/4/6/8/10: More than once a day/Once a day/4-6 times a week/1-3 times a week 


\begin{tabular}{lcccccccc}
\hline dictionary & & & & & & & & \\
\hline $\begin{array}{l}\text { 8. I use my PC/laptop as } \\
\text { dictionary }\end{array}$ & 49 & 26.34 & 21 & 11.29 & 37 & 19.89 & 38 & 20.43 \\
\hline $\begin{array}{l}\text { 9. I use the Internet as } \\
\text { dictionary }\end{array}$ & 172 & 92.47 & 14 & 7.53 & NA & & NA & \\
\hline 10. I use the Internet & 71 & 38.17 & 22 & 11.83 & 34 & 18.28 & 46 & 24.73 \\
\hline
\end{tabular}

4.4. Thoughts about kinds of dictionaries

As we can see in Table 4, 80.11\% of the respondents think that PDs are difficult to carry, $51.61 \%$ think that they are expensive, another $51.61 \%$ think that they are time consuming, but only $29.57 \%$ think that PDs are difficult to use. Overall, it is possible to argue that PDs are seen as the least practical of the other dictionary types mentioned in Table 4. On the contrary, only; $3.76 \%$ of the respondents think that CPs are difficult to carry as dictionaries, $2.15 \%$ of the respondents think that CPs are expensive to use as dictionaries, 5.91\% think that they are time consuming and only $4.30 \%$ think that CPs are difficult to use. Overall, we may argue that using CPs as dictionaries is seen as the most practical of all. Finally, $82.26 \%$ of the respondents think that PCs/laptops are difficult to carry as dictionaries, but only $12.90 \%$ think that PCs/laptops are expensive to use as dictionaries, and only $13.98 \%$ think that they are time consuming and only $15.05 \%$ think that they are difficult to use. Overall, it is possible to argue that using $\mathrm{PCs} /$ laptops as dictionaries is the respondents' second choice in terms of practical usage.

Table 4.Thoughts about kinds of dictionaries

\begin{tabular}{|c|c|c|c|c|c|c|}
\hline \multirow{2}{*}{ Statements } & \multicolumn{2}{|c|}{ Agree } & \multicolumn{2}{|c|}{ Disagree } & \multicolumn{2}{|c|}{ Undecided } \\
\hline & $\mathbf{N}$ & $\%$ & $\mathbf{N}$ & $\%$ & $\mathbf{N}$ & $\%$ \\
\hline 1.PDs are difficult to carry & 149 & 80.11 & 15 & 8.06 & 22 & 11.83 \\
\hline
\end{tabular}


An Investigation of ELT Student Teachers' Dictionary Ownership ... 227

\begin{tabular}{|c|c|c|c|c|c|c|}
\hline 2. PDs are expensive & 96 & 51.61 & 45 & 24.19 & 45 & 24.19 \\
\hline 3.Using PDs is time consuming & 96 & 51.61 & 47 & 25.27 & 43 & 23.12 \\
\hline 4. PDs are difficult to use & 55 & 29.57 & 99 & 53.23 & 31 & 16.67 \\
\hline $\begin{array}{l}\text { 5. CPs are difficult to carry as } \\
\text { dictionaries }\end{array}$ & 7 & 3.76 & 175 & 94.09 & 4 & 2.15 \\
\hline $\begin{array}{l}\text { 6. CPs are expensive to use as } \\
\text { dictionaries }\end{array}$ & 4 & 2.15 & 172 & 92.47 & 10 & 5.38 \\
\hline $\begin{array}{l}\text { 7. CPs are time consuming to use } \\
\text { as dictionaries }\end{array}$ & 11 & 5.91 & 167 & 89.78 & 8 & 4.30 \\
\hline $\begin{array}{l}\text { 8. CPs are difficult to use as } \\
\text { dictionaries }\end{array}$ & 8 & 4.30 & 168 & 90.32 & 10 & 5.38 \\
\hline $\begin{array}{l}\text { 9. PCs/Laptops are difficult to carry } \\
\text { as dictionaries }\end{array}$ & 153 & 82.26 & 16 & 8.60 & 17 & 9.14 \\
\hline $\begin{array}{l}\text { 10. PCs/Laptops are expensive to } \\
\text { use as dictionaries }\end{array}$ & 24 & 12.90 & 137 & 73.66 & 25 & 13.44 \\
\hline $\begin{array}{l}\text { 11. PCs/Laptops are time } \\
\text { consuming to use as dictionaries }\end{array}$ & 26 & 13.98 & 135 & 72.58 & 25 & 13.44 \\
\hline $\begin{array}{l}\text { 12. PCs/Laptops are difficult to } \\
\text { use as dictionaries }\end{array}$ & 28 & 15.05 & 136 & 73.12 & 21 & 11.29 \\
\hline
\end{tabular}

4.5. Locations where dictionaries are used

According to the results from Table 5, PDs and PC/laptops are mostly preferred at home with $80.11 \%$ and CPs are used most flexibly compared to other dictionary types. $16.67 \%$ of the respondents stated that they used CPs at home, $33.33 \%$ in the class, while $36.56 \%$ at outside locations and one in vehicles. In fact, CPs are preferred mainly at outside locations with $36.56 \%$ and in the class with $33.33 \%$. 
Overall, regardless of the kind of dictionary owned, it is possible to argue that using dictionaries "at home" is the most preferred option with an N-total of 329, followed by "in the class" with an N-total of 87 , and at "outside locations" with an N-total of 75. Using dictionaries in vehicles is the least preferred option with only $0.54 \%$, which can be counted as a non-existent preference for the respondents in this study. However, I believe that this may be due to the city condition where the respondents are currently studying, that is they do not spend much time travelling.

Table 5. User preferences about location

\begin{tabular}{|c|c|c|c|c|c|c|c|c|c|c|}
\hline & \multicolumn{2}{|c|}{ At home } & \multicolumn{2}{|c|}{ In the class } & \multicolumn{2}{|c|}{$\begin{array}{l}\text { At outside } \\
\text { locations }\end{array}$} & \multicolumn{2}{|c|}{ In vehicles } & \multicolumn{2}{|c|}{ Never } \\
\hline & $\mathbf{N}$ & $\%$ & $\mathbf{N}$ & $\%$ & $\mathbf{N}$ & $\%$ & $\mathbf{N}$ & $\%$ & $\mathbf{N}$ & $\%$ \\
\hline 1. I use my PD & 149 & 80.11 & 20 & 10.75 & 2 & 1.08 & 0 & 0 & 15 & 8.06 \\
\hline $\begin{array}{l}\text { 2. I use my CP } \\
\text { as dictionary }\end{array}$ & 31 & 16.67 & 62 & 33.33 & 68 & 36.56 & 1 & 0.54 & 24 & 12.90 \\
\hline $\begin{array}{l}\text { 3. I use my } \\
\text { PC/laptop as } \\
\text { dictionary }\end{array}$ & 149 & 80.11 & 5 & 2.69 & 5 & 2.69 & 0 & 0 & 27 & 14.52 \\
\hline
\end{tabular}

4.6. Reasons for using dictionaries

Results from Table 6 clearly demonstrate that dictionaries are mainly used to learn the meaning of vocabulary, with a $96 \%$ of the students stating this as "always-often and sometimes". The second reason for using dictionaries was to check meaning, with a $92 \%$. Checking spelling was the third reason with a $75 \%$, and learning spelling was fourth with a $73 \%$. Learning or checking the pronunciation of vocabulary were stated as the fifth and sixth reasons with a $62 \%$ and a $56 \%$ respectively. 
An Investigation of ELT Student Teachers' Dictionary Ownership ... 229

Table 6. Reasons for using dictionaries

\begin{tabular}{|c|c|c|c|c|c|c|c|c|c|c|}
\hline & \multicolumn{2}{|c|}{ Always } & \multicolumn{2}{|c|}{ Often } & \multicolumn{2}{|c|}{ Sometimes } & \multicolumn{2}{|c|}{ Rarely } & \multirow{2}{*}{$\begin{array}{c}\mathrm{Nev} \\
\text { er }\end{array}$} & \multirow[b]{2}{*}{$\%$} \\
\hline & $\mathbf{N}$ & $\%$ & $\mathbf{N}$ & $\%$ & $\mathbf{N}$ & $\%$ & $\mathbf{N}$ & $\%$ & & \\
\hline $\begin{array}{l}\text { 1. I use the } \\
\text { dictionary to learn } \\
\text { the meaning of } \\
\text { vocabulary }\end{array}$ & 95 & 51.08 & 74 & 39.78 & 10 & 5.38 & 5 & 2.69 & 2 & 1.07 \\
\hline $\begin{array}{l}2 . \text { I use the } \\
\text { dictionary to } \\
\text { check the } \\
\text { meaning of } \\
\text { vocabulary }\end{array}$ & 38 & 20.43 & 78 & 41.94 & 56 & 30.11 & 10 & 5.38 & 4 & 2.14 \\
\hline $\begin{array}{l}\text { 3. I use the } \\
\text { dictionary to learn } \\
\text { the spelling of } \\
\text { vocabulary }\end{array}$ & 29 & 15.59 & 52 & 27.96 & 55 & 29.57 & 44 & 23.66 & 6 & 3.22 \\
\hline $\begin{array}{l}\text { 4. I use the } \\
\text { dictionary to } \\
\text { check the spelling } \\
\text { of vocabulary }\end{array}$ & 30 & 16.13 & 46 & 24.73 & 65 & 34.95 & 40 & 21.51 & 5 & 2.68 \\
\hline $\begin{array}{l}\text { 5. I use the } \\
\text { dictionary to learn } \\
\text { the pronunciation } \\
\text { of vocabulary }\end{array}$ & 26 & 13.98 & 45 & 24.19 & 43 & 23.12 & 51 & 27.42 & 21 & 11.29 \\
\hline $\begin{array}{l}\text { 6. I use the } \\
\text { dictionary to } \\
\text { check the } \\
\text { pronunciation of } \\
\text { vocabulary }\end{array}$ & 25 & 13.44 & 41 & 22.04 & 38 & 20.43 & 56 & 30.11 & 26 & 13.98 \\
\hline
\end{tabular}


Thus, it is possible to come to conclude that the participants in this study use dictionaries in more conventional ways, despite the technological support that technology may provide for them, especially about pronunciation.

\section{Conclusion}

The purpose of the present study was to find out ELT student teachers' dictionary ownership and preferences in a Turkish university ELT department context, to discuss them under the light of the current literature and fill a gap in locally-situated research. The results reveal that university ELT student teachers in Turkey have similar attitudes and thoughts about dictionaries as their counterparts elsewhere in the world. Similar to previous research, a great majority (93\%) were of the opinion that foreign language learners need dictionaries, thus strengthening the previous arguments so far. As the participants were ELT student teachers, the $4^{\text {th }}$ classes soon to become ELT teachers, it is expected that they can use dictionaries effectively, however almost half $(47 \%)$ stated that they cannot use dictionaries effectively. This is probably due to the lack of dictionary usage training as stated by $81 \%$ of the respondents. Therefore, it is suggested that ELT departments in Turkey should provide dictionary training in effective dictionary usage.

PDs were the mostly owned (97\%) dictionary kind with a $67 \%$ of both mono and bilingual PD ownership. CPs as dictionaries were the second with $86 \%$ of ownership and with $51 \%$ of both mono and bilingual CP. Among the mostly preferred online web sites as sources for dictionaries are: tureng.com, zargan.com, and translate.google.com. PC dictionaries were also owned by a $79 \%$ of the respondents with a $59 \%$ of both mono and bilingual PC dictionary ownership. As regards PEDs, only $22 \%$ of ownership was recorded. Thus, it can be argued that PEDs are becoming extinct as a source for dictionary. In fact, CPs have replaced PEDs as they serve the same function. When it comes to using the dictionaries, we face a different scheme. Using the Internet as dictionary is the learners' first choice (92\%), CPs are the second (85\%), and PDs are the third (83\%). An 
overall evaluation reveals that using CPs as dictionaries has the most frequent usage frequency with $66 \%$ of average usage on a daily basis.

CPs were regarded as the most practical, PCs as the second and PDs the least practical dictionary types. In fact this finding helps us to understand as to why CPs are used as dictionaries most frequently by the student teachers in this study. In addition, CPs were used most flexibly; at home, in class and at outside locations. However, PCs and PDs were used mostly at home. An overall evaluation revealed that, regardless of dictionary kind, "home" was the place where dictionaries were used the most, "classroom" was the second and "outside locations" was the third. Data also revealed that the participants in this study used dictionaries in conventional ways despite all the technological support provided by today's dictionaries, such as CDs, DVDs, listening opportunities and even grammar support. This is mainly due to the fact that there is a lack of training in effective dictionary usage skills, especially as regards the possibilities of multimedia-based dictionaries.

Finally, under the light of the data obtained in this study, it is possible to argue that PEDs have almost become extinct as dictionaries and that PDs are losing their popularity. Thus, it seems that the the future of dictionaries will totally be shaped and dominated by various types of multimedia-based dictionaries. Therefore, it is suggested that lecturers and students in ELT departments in Turkey should consider ways of integrating multimedia-based dictionaries into the learning and teaching situations in general and try to explore more effective ways of using these dictionaries.

\section{References}

Ali, H. I. H. (2012). Monolingual dictionary use in an EFL context. English Language Teaching, 5(7), 2-7.

Battenburg, J. (1991). English Monolingual Learners' Dictionaries: A User-oriented Study. Tübingen: Max Niemeyer Verlag.

Bejoint, H. (1981). The foreign student's use of monolingual English dictionaries: A study of language needs and reference skills. Applied Linguistics, 2(3), 207-222. 
Bower, J., \& McMillan, B. (2006). Learner use and views of portable electronic dictionaries. Paper presented at JALT 2006, Community, Identity, Motivation, JALT Conference Proceedings, Tokyo.

Brumfit, C. (1985). Preface. In: R. Illson (ed.), Dictionaries, Lexicography and Language Learning (pp. 1-3). Oxford: Pergamon Institute of English Press.

Chan, A. Y. W. (2005). Tactics employed and problems encountered by university English majors in Hong Hong in using a dictionary. Applied Language Learning, $1-2,1-15$.

Dashtestani, R. (2013). EFL teachers' and students' perspectives on the use of electronic dictionaries for learning English. CALL-EJ, 14(2), 51-65.

Hamouda, A. (2013). A study of dictionary use by Saudi EFL students at Qassim University. Study in English Language Teaching, 1(1), 228-257.

Hasan, N. (2013). English dictionary ownership and usage among the Acehnese students in Malaysian University. Journal of Education and Practice, 4(4), 284292.

Nation, P. (2003). The role of the first language in foreign language learning. Asian EFL Journal, 5(2), 1-11.

Ryu, J. (2006). Dictionary use by Korean EFL college students. Language and Information Society, 7, 83-114.

Stein, G. (1989). EFL dictionaries, the teacher and the student. JALT Journal, 11(1), 36-45.

Şevik, M. (2014). University prep-school EFL learners' dictionary ownership and preferences. Procedia - Social and Behavioral Sciences, 158, 226-232.

Tomaszczyk, J. (1979). Dictionaries, users and uses. Glottodidactica, 12, 103-120.

Tseng, F. P. (2009). EFL students' Yahoo! Online bilingual dictionary use behaviour. English Language Teaching Journal, 2(3), 98-108.

Weschler, R. (2000). An experiment using electronic dictionaries with EFL students. The Internet TESL Journal, 6(8). Retrieved June 6, 2017, from /http://iteslj.org/Articles/Weschler-ElectroDict.html. 